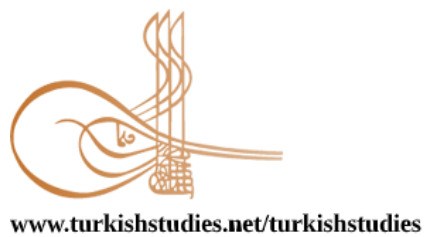

Turkish Studies

\title{
Bir Divan Şairi Olarak Kastamonulu İshâk-zâde Fevzî ve Şiirleri
}

\author{
İshâk-zâde Fevzî of Kastamonu As a Divan Poet and His Poems
}

\author{
Tarık Büyüm* - Mehmet Fatih Köksal ${ }^{* *}$
}

\begin{abstract}
A person who is a thinking and feeling entity has not been indifferent to what is happening around him in any period of his life. Human being felt the need to record some events, facts, emotions, excitements and pleasures that were affected during the adventure of life. Said registration process; as a result of the mood that the person is when affected, faced with likes, interested, or when in the face of a deeply shaking case, is a whole of actions that come out of transferring this feeling, to save it from forgetfulness, to writing. One of the memory spaces where this action is embodied are mecmuas and conks. Literary enthusiasts, some of whom are poets themselves, brought together the poems they liked, sometimes the poems of people around them, and sometimes their own writings in mecmuas or conks. Although this gathering act was the personal accumulation of that person, each of them also served as a poetry anthology, as well as carrying the historical social memory to the present. One of the works of this kind is the poem mecmua compiled by İshâk-zâde Fevzî of Kastamonu, which is the subject of our study. In this study, the mentioned mecmua of İshak-zade es-Seyyid Hâfiz Hasan Fevzî of Kastamonu, one of the poets of the 19th century, was briefly introduced, the life and literary personality of Fevzî was handled and finally his poems in the mecmua were published.
\end{abstract}

Structured Abstract: Although there is no information about the old and new general sources, we can also say that we would like to underline the reason for writing this article before moving to the life and literary personality of Ishak-zade Fevzi, who has scattered information in the local studies carried out in the Republican period of Turkey, in various books, anthologies, articles and papers. It is that Fevzi is presented almost entirely as a folk poet, Minstrel (Instrumental) poet or lover in the current works, his interest in the Diwan poetry and the mention of "Fevzi as a Diwan poet" has never been touched. In this, it is understood that being unaware of the poetry periodical which is always mentioned but not available, has a great role. The only full copy of this periodical that comes from the author is the voluminous copy in the M. Fatih Köksal Library as far as we know. Fevzi also included 17 of his own poems in this work, which is a valuable local poetry periodical especially in terms of hosting poets from Kastamonu region. His choice in both his poems he got in the previously metnioned periodical and other poems he recorded in his periodical is a clear indication that he has a serious accumulation of Classical poetry not only in terms of poetry but also in his pleasure, knowledge and understanding of poetry.

\footnotetext{
* Yüksek Lisans Öğrencisi, Amasya Üniversitesi, Sosyal Bilimler Enstitüsü, Türk Dili ve Edebiyatı Anabilim Dalı Graduate student, Amasya University, Enstitu of Social Sciences, Department of Turkish Language and Literature ORCID 0000-0003-4813-6663

tarik.shapsig@gmail.com

** Prof. Dr., İstanbul Kültür Üniversitesi, Fen Edebiyat Fakültesi, Türk Dili ve Edebiyatı Bölümü

Prof. Dr., İstanbul Kültür University, Faculty of Science and Arts, Department of Turkish Language and Literature ORCID 0000-0003-1056-9957

mfkoksal@gmail.com

Cite as/ Atıf: Büyüm, T. \& Köksal, M. F., (2020). Bir divan şairi olarak Kastamonulu İshâk-zâde Fevzî ve şiirleri.

Turkish Studies, 15(3), 1965-1981. https://dx.doi.org/10.29228/TurkishStudies.43018

Received/Geliş: 22 April/Nisan 2020

Accepted/Kabul: 20 June/Haziran 2020

Checked by plagiarism software

Copyright $(\mathrm{C}$ MDE, Turkey

Published/Yayın: 25 June/Haziran 2020

CC BY-NC 4.0
} 
Fevzi's periodical is a highly voluminous poetry that contains 591 poems of 392 poets, most of whom are poets belonging to the Alevi/Alawi-Bektashi and Hurufi belief system, some of them are Kastamonu region poets, and a remarkable part of them are well-known poets of Turkish literature.

In the periodical we have, 14 of the 17 poems belonging to Fevzi are ghazals and one of them is murabba, muhammes and kit'a (verse). In the main axis of Fevzi's poems, there are writings written around the Alevi/Alawi-Bektashi belief system and manzumes trying to continue the classical poetry style. In addition, he has a naat written for the Prophet Muhammad and also a eulogy he wrote on behalf of Pir Sa'ad ad-Din, who is understood to be his sheikh.

Ishakzade Fevzi, who made long-term trips to Anatolia with his Saz on his back in the past and became very dominant in playing Saz during this period, also in the following period, he began to write manzumes in the style of Classical poetry. In his seventeen poems, which Fevzi recorded in his compiled periodical, he frequently mentions Hazrat Ali, Hazrat Hussain and Hazrat Hassan, and frequently refers to the case of Karbala especially in his poems he wrote around the Alevi/Alawi-Bektashi belief system. The poet, who occasionally sings ghazels in love and pleasure, also included a poetric conundrum in his periodical.

It is a known issue that the life experienced in the 19th century had a stronger effect on Classical poetry than previous times, and in this period many new, local and even European elements could be easily seen in poetry. It is possible to see the obvious manifestations of this situation in Fevzi's poems. In addition, especially in his poems, which he wrote in the classical style, the effects of the poet Nedim are very obvious. However, he could not catch the elegance and grace and agility in this poet he followed.

In this article, the valuable and tidy voluminous periodical which is kept by the poet Ishakzade Fevzi, who is known as an important poet in Kastamonu region, and which is valuable in terms of getting to know the poets of Kastamonu region, has been dealt with in a way that has not been metioned until today and all the poems of the owner of this periodical in the style of Classical Turkish Literature and his poetry were tried to be introduced to the world of science.

Keywords: Mecmua, poem mecmuas, İshak-zade Fevzî of Kastamonu

Öz: Düşünen ve hisseden bir varlık olan insan, hayatının hiçbir döneminde çevresinde olup bitenlere kayıtsız kalmamıştır. İnsanoğlu, hayat serüveni esnasında etkilendiği kimi olayları, olguları hatta duygularını, heyecanlarını, zevklerini kayıt altına alma ihtiyacı hissetmiştir. Söz konusu kayıt işlemi; kişinin etkilendiği, beğendiği, ilgi duyduğu veyahut kendini derinden sarsmış bir vaka karşısında içinde bulunulan ruh hali neticesinde, tüm bu hissiyatı unutulma marazından kurtarma amaçlı yazıya aktarmakla ortaya çıkan eylemler bütünüdür. Bu eylemin vücut bulduğu hafiza mekânlarından biri de mecmualar ve cönklerdir. Bazıları kendisi de şair olan edebiyat meraklıları, beğendikleri şiirleri, bazen kendi çevrelerindeki insanların manzumelerini bazen de kendi yazdıklarını mecmua veya cönklerde bir araya getirmişlerdir. Bu toplama eylemi o kişinin kişisel birikimi olsa da bu derlemelerin her biri bir yanıyla birer şiir antolojisi olurken bir yanıyla da tarihî/toplumsal hâfızayı bugüne taşımak gibi bir işlev de görmüştür. Bu türden eserlerin birisi de çalışmamıza konu olan Kastamonulu İshâk-zâde Fevzî’nin derlediği şiir mecmuasıdır. Bu çalışmada, XIX. yüzyıl şairlerinden Kastamonulu İshâk-zâde es-Seyyid Hâfız Hasan Fevzî’nin söz konusu mecmuası kısaca tanıtılmış, Fevzî’nin hayatı ve edebî kişiliği ele alınmış ve nihayet mecmuada yer alan şiirleri yayımlanmıştır. Hem âşık edebiyatı hem divan edebiyatı tarzında şiirler kaleme alan İshâk-zâde Fevzî’ den bahseden çalışmalarda onun daha ziyade halk şairi tarafı öne çıkarılmıştır. Hâlbuki mecmuasına aldığı şiirlerinden anlaşıldığına göre o, klasik şiir tarzında yazdığı manzumelerle de değerlendirilmesi gereken bir şairdir. Bu makalede Fevzî, bu yönüyle değerlendirilmiştir.

Anahtar Kelimeler: Mecmua, şiir mecmuaları, Kastamonulu İshak-zade Fevzî.

\section{Giriș}

Klasik Türk Edebiyatı'nın altı asırlık macerasında, Osmanlı coğrafyasının hemen her köşesinde takipçileri olmuştur. Kastamonu da bu edebiyatın icrası ve yaşatılması açısından öteden 
beri mühim bir merkez olagelmiştir. Uzun soluklu bu edebiyatın son devresine yetişebilen Fevzî, hem âşık edebiyatı hem de divan edebiyatı sahasında şiirler söylemiş bir şairdir.

"Bilindiği gibi XIX. yüzyıla gelinceye kadar Osmanlı padişahlarının çoğu genellikle şiir ve edebiyatla ilgilenmişler hatta kendileri şiir yazmışlardır. Ancak, XIX. yüzyılda yüzyılın başında padişah olan ve İlhami mahlasıyla şiir yazan III. Selim dışındaki padişahlar, şiir ve edebiyatla hemen hiç ilgilenmemişler; böylece sarayın edebiyatla uğraşma geleneği dönem içindeki ömrünü tamamlamıştır. XIX. yüzyılda divan şiiri, Yeni edebiyat karşısında gücünü kaybetmiş hatta kendi geleneği içinde bile değerini koruyamaz duruma düşmüştür." (Mengi, 2017: 261). Saraydan destek görememesi Klasik şiirimizin bu dönemde artık yok olma tehlikesiyle baş başa kalmasının tek gerekçesi değildir ama bu yoksunluk oldukça önemli bir etkendir. Ülkenin artık Batı'ya bütünüyle açılmış bir pencereden de bakmasının, özellikle aydın kesim arasında bu eski şiir tarzından uzaklaşmayı da beraberinde getirdiği bilinen bir husustur. Son döneminde hemen her bakımdan ayrılıklar görülen Osmanlı fikir ve sanat dünyasının klasik şiire bakış noktasında da ayrıldığı bir vakıadır. Nitekim kimi şairler bütünüyle Batı tarzına yönelirken kimileri ısrarla eski tarzı devam ettirme yolundaydılar. Hatta kimileri bir yanıyla Tanzimat aydınlarının ortaya koydukları usûl ve üslûbu takip ederken bir taraftan da gazeller, kasideler, rubailerle alıştıkları şiir geleneğini devam ettiriyorlardı. İşte böyle karmaşık ve klasik şiirimizin can çekiştiği bu dönemde Fevzî’nin şairlik bakımından orta derecede bir kabiliyet olduğunu söylemek galiba yanlış olmayacaktır.

Hakkında eski-yeni genel kaynaklarda bilgi bulunmamakla birlikte, Cumhuriyet döneminde yapılan -özellikle yerel- çalışmalarda, türlü kitap, antoloji, makale ve bildiri metinlerinde bölük pörçük bilgiler bulunan İshâk-zâde Fevzî’nin hayatı ve edebî kişiliğine geçmeden önce bu yazının kaleme alınma sebebi de diyebileceğimiz bir hususun altını çizmek isteriz. O da Fevzî’nin mevcut çalışmalarda hemen tamamen bir halk şairi, saz şairi veya âşık olarak takdim edilmiş, divan şiiriyle ilgisine ve "bir divan şairi olarak Fevzî" bahsine hemen hiç temas edilmemiş olmasıdır. Bunda öyle anlaşılıyor ki, hep sözü edilen ama elde bulunmayan şiir mecmuasından habersiz olunmasının rolü büyüktür. Bu mecmuanın müellifin elinden çıkma ve tam olan yegâne nüshası bildiğimiz kadarıyla M. Fatih Köksal Kütüphanesi’nde bulunan hacimli nüshadır. ${ }^{1}$ Özellikle Kastamonu yöresine mensup şairleri de barındırması açısından değerli bir yöresel şiir mecmuası olan bu eserde ${ }^{2}$ Fevzî’nin kendisinin de 17 manzumesi mevcuttur. Gerek buraya aldığ 1 kendi şiirleri gerekse mecmuasına kaydettiği diğer şiirler, onda sadece şairlik bakımından değil şiir zevki, bilgisi ve anlayışı olarak da ciddi bir klasik edebiyat birikimi olduğunun açık göstergesidir.

\section{Fevzî'nin Hayatı}

İshâk-zâde Fevzî’nin Türk Dili ve Edebiyatı Ansiklopedisi, Türk Dünyası Şairler ve Yazarlar Sözlüğ̈̈ gibi biyografik/ansiklopedik mahiyetteki eserlerde yer almaması önemli bir eksikliktir. Onun hayatı ile ilgili çeşitli kaynaklardan derlediğimiz bilgileri aşağıda aktaracağız. Ancak ona dair bilgileri ihtiva eden ilk elden ve en sahih kaynak esasında derlemiş olduğu ve yazımızda konu edilen mecmuasıdır. O, mecmuasında kendini tanıtma hususunda oldukça ketum davranmış, derkenarlardaki kısa bilgi notlarında -daha ziyade mütevazı ifadeler ile- kendisine dair kısa ipuçları vermekle yetinmiştir. "Buna göre kendisini 'es-Seyyid' olarak niteleyen şair peygamber soyundan gelen sâdâttandır. Kastamonuludur. Adı Fevzî, künyesi İshâk-zâde’dir. Fevzi, Hacı Ahmed

\footnotetext{
${ }^{1}$ Mecmuayla ilgili bizi (MFK) arayan Kastamonu Üniversitesi öğretim üyesi Prof. Dr. Eyüp Akman yaptığımız telefon görüşmesinde bizi mecmuanın muhtasar bir nüshasının varlığından haberdar etmişti. Değerli halkbilim araştırmacısı M. Sabri Koz da Bizdeki mecmuayla aynı renkte kâğıda ve aynı hatla yazılmış olmasına nazaran vaktiyle bundan kopmuş olduğu anlaşılan birkaç yaprağın kendisinde olduğunu haber vererek fotoğraflarını gönderme nezaketinde bulunmuştu. Sayın Koz'a ve diğer nüshayı haber veren Akman'a teşekkür ederiz.

${ }^{2}$ Kastamonulu değerli folklor araştırmacısı Nail Tan, bir görüşmemizde (MFK) bu mecmuayı Türk Folklor Kurumu'na almak için çok çaba sarf ettiğini ama aileyi ikna edemedikleri için buna muvaffak olamadıklarını söylemiş ve mezkûr mecmuanın kadirbilir bir elde bulunmasından duyduğu hoşnutluğu ifade etmişti. Bu çalışma ve daha önce yapılanlar bir anlamda, layık görülen "kadirbilirlik" sıfatına nail olabilme gayretleri olarak kabul edilmelidir.
} 
Şevkî'den ve Nakşîbendî şeyhlerinden Şeyh Ahmed-i Siyâhî’den dersler almıştır” (Köksal, 2010: 356).

Kaynaklarda geçmeyen bir bilgi olarak mecmuasında yer alan ve aşağıda tam metnini verdiğimiz, adına gazel tarzında bir methiye yazdığı "Pîr Sa'deddîn"in müridi/bağlısı olduğunun anlaşıldığını da söyleyebiliriz. Elbette mecmuasındaki özenli ve güzel yazısı, yer yer Gubari tarzına yakın, çıplak gözle zor görülür incelikte yazısına nazaran onun hattatlık yönünün olduğunu da hakkındaki bilgilere eklemek gerekir.

Kastamonulu divan şairleri üzerine yapılan kimi çalışmalarda (Kılıç, 2003; Yazar, 2003; Kaçalin, 2003) yer almayan şairle ilgili ilk bilgileri Talat Mümtaz Yaman (1936) vermektedir. Daha sonra yine bir Kastamonulu olan Nail Tan'ın bir tebliğinde (1987) şairden bahsedilir. Nihayet Kastamonulu âşıklar üzerine yapılan bir yüksek lisans tezinde (Yücel 1993) ve bazı diğer çalışmalarda da (Şenel, 1995; Yüksel Halıcı 2013) şairimiz bahse konu edilmiştir. Kastamonulu divan şairleri üzerine yapılan en son çalışmada da (Aydın 2019) Fevzî’ den bahsedilerek hayatı, edebî kişiliği, şiirleri hakkında bilgiler verilmiştir.

“Fevzî, 1273/1857'de Kastamonu Cebrail Mahallesi'nde dünyaya gelmiştir. Kastamonu Rüştiyesi'nde okumuş ve medreseye devam ederek Bâkî-zâde Abdullah Efendi'den ders almış, Seyyid Ahmed Hicâbî'den de icazet almıştır. Kastamonulu divan şairlerinden Celâlî'den de dersler almıştır" (Aydın, 2019: 103). Kastamonulu İshâk-zâde Fevzî, öncelikle halk âşığ1 olarak âşık edebiyatı sahasında şiirler söylemiş, ilerleyen yaşlarında klasik Türk şiirine temayül etmiştir.

"Fevzî Hasan henüz on üç yaşında şiir söylemeye başlamış, şöhretli saz şairlerine çıraklık etmiştir. Önce Sinoplu Yesâri Baba'ya çırak olmuş sonra Âşık Kemâli’ye bağlanmıştır." (Aydın, 2019: 103). "Anadolu'nun değişik şehirlerinde birçok mimari esere ve vefat eden önemli kişilere dair tarih şiirleri bulunmaktadır. Bu durum belli bir dönemden sonra şairin divan şiirine yöneldiğini göstermektedir. Zira koşmalarında da divan şiiri etkileri vardır" (Halıcı, 2013). "Fevzî Hasan gelir durumu iyi olduğu için çalışma hayatına atılmamıştır. Aynı zamanda halk âşı̆̆ı olan Fevzî, tüm zamanını saza ve söze adamıştır. Elinde sazla Anadolu'nun içlerine biri üç diğeri yedi yıl süren iki seyahat düzenlemiştir" (Aydın, 2019: 103). Kısa süren çalışma hayatında kâtiplik yaptığ da bilinmektedir. 1324/1907 y1lında Kastamonu Vergi Dairesi'ne memur olmuş, yaklaşık on y1l sonra tifodan vefat etmiştir (Halıcı, 2013).

Fevzî, divan edebiyatı sahasında da âşık edebiyatı sahasında da kendisini yetiştirmiş bir şairdir. "Şairliğinin ilk zamanları tamamı ile halk şairlerine hizmet etmiş ve bir halk şairi olmak istemiş, bu yüzden çok mükemmel ve usullü saz çalmasını da öğrenmiş, hatta sazı omzunda pek çok yerleri dolaşmış ve âşıkâne fasıllar da yapmıştır" (Halıcı, 2013). Fakat sonraları kendisini tamamıyla divan edebiyatına kaptırmış ve Muallim Naci edebî devrinin bir mukallidi olmak arzusundan kendisini kurtaramamıştır (Yaman 1936: 12, Halıc1 2013'den).

\section{Eserleri}

İshâk-zâde Fevzî’nin bilinen üç eseri mevcuttur: Hâtırât-ı Fevzî, Füsûl-ı Âşılkân, Mecmû'a$i$ Eş'âr (Aydın, 2019: 104). Elimizde söz konusu iki esere dair herhangi bir bilgi yoktur. Bu noktada tanitabileceğimiz yegâne eser Mecmû'a-i Eş' $a ̂ r^{\prime}$ 'idır. ${ }^{3}$

\footnotetext{
${ }^{3}$ Mecmua hakkında daha ayrıntılı bilgi daha önceki bir çalışmada (Köksal 2011) bilgi verildiği için burada bu bahis kısa tutulmuştur.
} 


\section{Mecmû'a-i Eş'âr, M. Fatih Köksal Özel Kütüphanesi, Yz. 71-Mec. 10.}

"170-105 mm dış ölçülerinde, iç ölçüleri muhtelif; 292 yaprak; satır sayısı muhtelif; sonradan yapılmış bordo bez kaplı mukavva cildin meşin sırtı üzerinde Latin harfleriyle "Şiir Mecmuası" yazmaktadır. Mavi renkli, üç çizgi filigranlı kâğıda nefis nesih hatla 1293-1297 yılları arasında yazılmıştır”. Mecmua, önemli bir kısmı Alevî-Bektaşî ve Hurûfî inanç sistemine mensup 392 şairin 591 şiirini barındıran oldukça hacimli bir şiir mecmuasıdır (Köksal, 2013: 320-321). Klasik Türk şiirinin ve Türk tasavvuf şiirinin şöhretli şairlerinin de yer bulduğu mecmuada Kastamonu ve civarında yetişen şairler de mevcuttur.

Mecmuada şiiri bulunan şairler şunlardır (Köksal vd. 2018: 243-5):

Abdâl (124a), Abîdî 230a, Adlî (244b), Âgâhî (240b, 284a), 'Âhid (65b), Ahmed-i Dâ'î (290a), Ahmedî (144b), Âkif (292b), Aklî (246b), Âlî ( 152 ) (آلى, 287b), 'Âlî (76a, 228b), 'Âlî Paşa (243a), Ârif (27b, 36b, 112a, 114a, 153b, 206a, 217a), 'Arîf (278a), Ârifí (251b), Âsaf (168a), Âsim (286b), Âş1k Ömer (146b, 150b, 222b), Atâyî (240a), Aynî (40b, 202b, 203a, 227b, 264b), Bahâyî (260b, 263b), Bâkî (58a, 172b, 259a, 259b, 259b, 283a, 283b, 283b), Bâzî (280b), Bedrî (126b, 197a), Behcet (227b), Belî̆g (272a, 288a), Ca'ferî (288a), Celâlî (285a), Cem (Sultân Cem) (152b), Cem'î (262b, Cesârî (151a), Cevâbî (130a, 209b), Cevdet (289a), Cihâdî (252b), Çâkerî (210a), Dehrî (252a, 255a), Dertli (82a, 158b), Dervîş Ömer (209a), Dervîşî (169b), Dervîşî Baba (232b), Dilşâdî (97a, 216a), Dürrî (154a), Ecrî (49b, 86a), Edhem (284a), Emrâhî (1a, 1b, 2a, 2a, 2b, 3a, 4a, 5b, 6b, 8a, 9a, 10b, 12a, 12a, 13a, 13b, 14a, 14b, 15a, 15b, 16a, 16b, 17a, 19a, 20b, 21a, 23a, 183a), Erbâbî (249a), Es'ad (264a), Esrârî, (251a), Esrârkeş Baba (), Derûnî (148a), Eşref-zâde Rûmî (39a, 123b), Fâik (287a), Fâ'iz (58b, 59a, 245a, 262a), Fahrî (284b, 287a), Fazlî (42b, 217b, 237a), Fedâyî (251a), Fehîm (125b, 216b, 292a), Fehîm-i Taşköprî (226a), Fehmî (274b), Fenâyî (238a, 286a), Ferîde Hanım (Bahâr-zâde) (166b), Ferrî (161a), Fethî (238b), Fevzî (107a, 138b, 166b, 201a, 210b, 211a, 211b, 232b, 233a, 234a, 234a, 243b, 258a, 258b, 277a, 277b), Feyzî (155b), Fuzûlî (121b), Gafûrî (229b), Gâlib (279a), Garîbî, (235a, 269a), Garîbî (A'mâ Yûsuf) (41a), Hâfiz (28a), Hafîdî (198b, 223b, 276b), Hâk-i Mahzûnî (179a), Hâkim (72b), Halîlî (129a, 256a), Hâlisî Çelebi (264b), Hamdi (115a), Hâmî (268a), Hanîf (237b), Hanîfî (104b), Hasbî (121a), Hasmî (161b), Hâş̧im (208a), Haşmet (261b, 281b), Hatâyî (116a, 150a), Hâtem (57b), Hayrî (154b, 253a), Hifzî (262a, 278b), Hikmet (289a), Hilmî (43b, 155a, 193b, 236b), Hisârî (280b), Hitâbî (142b), Hulûsî (252a), Hurrem (248a), Huşûi (158a), Hüdâyî (196a), Hüseynî (214a), Hüseynî Çelebi (60b), Hüsnî (186b), Hüsrev Efendi (225a), İbrâhîm (125a), İkbâlî (256b), İlhâmî (186a), İlhâmî (Sultân Selîm) (236a), İrşâdî (167a, 169b, 251a), İshâk (226a), İsmâîl Hakkî (26a, 35a, 46a, 135a, 217b, 218a), İsmetî (54b, 283b, 247b), İşretî (230a), İtâbî (287b), İzzet (Amasyalı İzzet Efendi) (143a), Kabûlî (151a, 231a, 241b), Kâmî (157b, 228b, 287b), Kâmil (45a, 136a, 191b), Kanberî (77a), Kânî (28b, 221b), Kâzım (98a, 272b), Keçeci-zâde İzzet (218b), Kemâlî (282b), Kemâlî Baba (249b), Kenzî (33b), Kerîmî (219b), Kırkkiliseli Şevket (185b), Kuddûsî (45b), Lâmiî Efendi (52a), Latîf (223a), Lebîb (32b, 207a), Lem'î (282b), Leylâ Hanım (26b, 27a, 74b, 258b, 265b), Mâhir-i Kadîm (157a), Mahmûd Hüdâyî (29a, 134b), Mahsûlî (157a), Mahvî (33b), Mantıkî (163b), Mecdî (246a), Medîhî (58b), Meftûnî (Sultân Mustafa) (192b), Menbaî (241a), Menzî (213b), Merâmî (151b), Meşrebî (132a), Mevzûnî (270b), Meydânî (215a), Mezâkî (245b), Micmerî (138a), Mihrî (36b), Mîr Fâzıl (57a), Mîr Hakkî (İsmâîl Paşa-zâde) (269b), Mîr Kâzım (51b), Mîr Necâtî (61a), Mîr Saîd (164a), Mir’âtî (49b, 67b, 124a, 231a, 233b), Misâlî (116b), Muhibbî (Sultân Süleymân) (52b, 164b), Muhyî (132b, 196b), Murâd (244a), Murâdî (153a, 161a), Murâdî (Sultân Murâd-1 Sâlis) (56b), Münîr (227a), Müslimî (245b), Müştâk (66a, 225b, 242b, 273b), Nâilî (162a, 267b), Nâbî (43b, 65a, 204a, 253b, 268a), Nahîfî (33a, 51a), Nakşî (198a, 238a, 279a), Nâlî (32b), Nazîf (32a), Nazîm (40a, 278a), Nâzim (66a), Nazmî (200a), Necîb (184a), Nedîm (282a), Nedîm (Mahmûd Nedîm Paşa) (187a), Nef'î (156b, 165a), Nesîb (265a), Nesîmî (134a, 134b, 194b, 195b, 199a), Neş'et (64a, 71a, 185b, 190b, 235b, 260a), Neş'et Efendi (29b), Nev'î (55a, 254a), Nevres (168b, 257a), Nevres Paşa (241b), Nihâd (62b, 62b, 167b), Nihânî (255a), Niyâzî (131b, 153b, 169a, 188a), Niyâzî-i Cedîd (181b, 223b, 271a), 
Niyâzî-i Hayder (267a), Nizâmeddîn (118a), Nûrî (226b, 248b, 249a), Nûrî-i İskilibî (41b), (Nûrî-i Kadîm (122b), Nûrî-i Tokâdî (61b, 176b, 178a), Nüzhet (25b, 53b, 280a), Osmân Nevres (237a), Pertev (63a, 64a), Pertev Paşa (257a), Râif (249a), Rahmî (171b, 270b), Râsih (159b, 250a, 250b), Râşid (244a), Re'fet (242a, 270a, 290b), Refî'-i Kâlâyî (37a, 70a), Resmî (148a), Reşîd (279b), Reşîdî (126a, 136b), Revânî Baba (232a), Rızâ (30a, 31a), Rızâ Beşiktaşî (39b), Rizâ Paşa (160)a, Riyâzî (255b), Rûhî (219a, 219a, 234a, 224a), Ruhî-i Bagdâdî (55a, 64b, 267b), Rûhî-i Kadîm (170b), Rüşdî (268b), Sâbir (162b), Sâbit (263a, 287a), Sabrî (291a), Sabûhî (256a), Sâdık (180b, 181b), Sa'dî (20b, 20b, 247a, 256b, 261a, 290b), Safder (168a), Sâfî (140b, 141b, 244b), Safvet (50a), Sâib (278b), Saîd Efendi (205b), Salâhî (285b), Sâlim (250a Sâyî (276a), Sâmî (38a, 254a, 266b, 273a), Sâyî (276a), Sânî (60b), Saydî (131a, 138b, 139b, 253a Sâyî (276a), Selâmî (45a, 109b, 110b, 184b, 212a, 212a, 220b, 221a, 222b), Semâyî (239b, 102a), Sermed (46b), Seyfî (44a, 80b, 128b, 214b, 215a), Seyyid Ahmed Hicâbî (122b, 123b), Seyyid Seyfî (75a), Siddık Ali Baba (25a), Sidkî (129a, 162b), Sıdkî-i Kastamonî (201b), Subhî (279b, 287b), Sultân Mehmed Hân (Muhammed mahlasl1) (159a), Sultân Mustafa (192b), Süleymân Fehmî (47a, 57a), Sürûrî (129b, 186a, 186b), Şâdî (250b), Şâkir (127b), Şâmî (43a), Şefîk-i Hanyevî (54a), Şehdî (60a, 155b), Şem'î (85a, 165b, 166a, 291a), Şem'î-i Konevî (35b, 36a, 120b, 165a, 204a, 204b, 234b), Şemsî (47b), Şemsî Paşa (152a, 231b), Şemsî-i Sivasî (122a, 263a), Şerefî (274a), Şevkî (44b, Şeyh Cemâlî (130b), Şeyh Gâlib (Es'âd mahlasiyla) (92a, 137b), Şeyh Rizâ (133b, 205b, Şeyh Selâmî (38a, 136a, 137a, 175b), Şeyh Sezâyî (202a), Şinâsî Bey (55b), Şühûdî (239a), Şükrî (261a), Tahsîn (284b), Tâlibî (128a), Tîgî (93b, 229a), Türâbî (88b), 94b, 145b, 260a), Udmî (275a), Ulvî (96a, 126a, 171a, 239b), Ulvî Efendi (53a), Usûlî (114b, Vâfî (106a), Vahdetî (116a), Vahîd (163a, Vasfî (285a, 285b), Vâsıf (199b, 63b, 64a, 265b, 266a), Vâsıf-1 Enderûnî (26b, 145a, 145a, Vecdî 280a, 292a), Vehbî [Sünbül-zâde] (257b), Vehbî (281a, 281b, Vesîm (246b, Vîrânî (74a, 75a, 78b, 83b, 117a, 213a), Vüsûlî (291a), Yahyâ (254b), Yahyâ Efendi (28a, 59b), Yehûdâ (174a), Yemînî (117a), Yesârî (87b, 212b, 263b, 289b), Yetîmî (273b), Yûsuf Ziyâ Paşa (160b, Zahmî (51b, 90a, 91a, 103b), Zâtî (135b, Zekâyî (34a, 34b, 38b, 39b, 108a, 207b, 222a), Zekî (286b), Zihnî (48a, 48b, 66b, 156a, 225a), Zihnî-i Çermîkî (37b, 242b), Ziyâ (54a), Ziyâyî (281a), Zuhûrî (228a).

Baş: Cemâlüñ bâğ1 ey dil-ber gül-i zîbâya nâz eyler

Boyuñ bir servdür ammâ şeh-i tûbâya nâz eyler

Son: Kaçan yâd eylese câm-1 leb-i la'lüñ gönül cânâ

Akar hûn-âb olur çağlar dükenmez çeşme-i dîdem

\section{Şairliği}

Yukarıda şairin hayatıyla ilgili bölümde, edebî kişiliğine ve şairliğine dair muhtelif çalışmalardan derlenen bazı bilgilere yer verilmişti. Fevzî'nin şiirlerini tespit ve onu sanat kabiliyeti açısından değerlendirmeye tabi tutabileceğimiz asıl kaynak ise yine onun derleyicisi olduğu mecmuasıdır. Elimizde bulunan mecmuada 17 adet şiir örneğinin 14'ü gazeldir. Birer adet de murabba, muhammes ve kıt'ası vardır. Gazellerin biri 6 , diğerleri beşer beyitten müteşekkildir. Kıta 2 beyit, murabba 3 , muhammes 4 bendden oluşmaktadır.

Mecmû'a'nın 232b sayfasındaki "Ṣāḥib-Muharrer Fevzị Efendiniñ Ġazeliyātınıñ Bażısı" kaydından hareketle Fevzî’nin mecmuaya aldıklarından başka gazelleri de olduğunu anlıyoruz.

Fevzî'nin mecmuasına kaydettiği şiirlerinin aruz kalıplarının dağılımı şöyledir:

fe'ilâtün/ fe'ilâtün/ fe'ilâtün/fe'ilün: 7 şiir

mef'ûlü/mefầ'̂̈lü/ mefầ'̂̂lü/fe'ûlün: 6 şiir

fầ'ilâtün/ fâ'ilâtün/ fầ'ilâtün/fầ'ilün: 2 şiir 
mefầ'îlün/ mefầ'îlün/ mefầ'̂̀lün/ mefâ'îlün: 1 şiir

fầ'ilâtün/ fầ'ilâtün/fầ'ilün: 1 șiir

Şiirlerinde yer yer aruz kusurlarına rastlanan Fevzî’nin bazı şiirlerinde vezin çok akıcı ve rahat iken bazılarında aksamalar mevcuttur. Aruz kusurlarına metin üzerinde dikkat çektiğimiz bu manzumelerinde daha çok aruzun yukarıda gösterilen rahat ve akıcı kalıplarını tercih etmesi aslında hem aruz hem heceyle yazan şairlerde çoğunlukla görülen bir yaklaşımdır.

Fevzî'nin edebî kişiliğine ve şairliğine dair söyleyeceklerimiz mecmuamızda yer alan şiirlerden hareketle olacaktır. Bütün şiirleri bir araya getirildiğinde bu yorum ve değerlendirmelerde farklılık olması elbette mümkün ve muhtemeldir. Onun şiirlerini muhteva açısından değerlendirmek suretiyle şiir kabiliyetini, şahsi hassasiyetlerini, şiirinin ana eksenini oluşturan kavramları bir şemsiye altında toplayabiliriz. Fevzî'nin şiirlerinin mihverinde Alevî-Bektaşi inanç sistemi çevresinde yazılanlar ve klasik şiir tarzını devam ettirmeye çalışan manzumeler bulunmaktadır. Bunun yanı sıra bir naati ve bir de şeyhi olduğu anlaşılan Pîr Sa'deddîn adına yazdığı methiyesi mevcuttur.

19. yüzyılda, yaşanan hayatın klasik şiire önceki devirlerden daha kuvvetli bir şekilde tesir ettiği, şiire birçok yeni, yerel hatta Avrupaî unsurların rahatlıkla görülebildiği bilinen bir husustur. $\mathrm{Bu}$ durumun bariz tezahürlerini Fevzî'nin şiirlerinde de görmek mümkündür. Aşağıdaki beyitte sevgilisinin Avrupaî tarzda saçından söz ediyor:

Avrupa perçemine Fevzī nigāhım olalı ${ }^{4}$

Ol zamāndan berü gīsū-y1 perīşān severim

Keza şu beytin ilk mısraı klasik dönem divan şairi üslûbundayken ikinci beyitte adeta terdid sanatı yaparcasına okuru şaşırtıyor:

Söyle ey bād-1 șabā bir gice teşrîf itsün ${ }^{5}$

Tā țopuḳdan dize dek şalvar-1 vaṣlın çözelim

"Âdeta" dememizin sebebi, Fevzî’nin burada böyle bir niyeti olmamasından dolayıdır. Aşığın "bâd-1 sabâ"dan sevgiliden haber getirmesi veya götürmesini istemesi klasik şiirde çok işlenen bir motiftir. Sevgilinin "gece teşrifi”" tabirinde Nâilî’nin;

Kadem kadem gece teşrîfi Nâ'ilî ol mehin

Cihân cihân elem-i intizâra değmez mi

beytinin tesiri olduğu muhakkak. Buraya kadar her şey normal ama ikinci mısradaki tamamen cismanî arzulara dayalı ifadeler -bütün bir dönemi şamil olmasa da- bu asır şiirinin bir özelliğidir. Bunu, Nedîm'in daha 18. yüzyıl başlarında ustaca başlattığı "şûhâne" söyleyiş tarzının bir sonraki asırda Vâsıf'ın dilinde zarafet elbisesini çıkarması ve nihayet sadece kronoloji değil mertebe itibarıyla da arkadan gelen şairlerin kaleminde büsbütün pespayeleşmesinin bir tezahürü olarak değerlendirmek mümkündür. Nitekim aynı şiirin hemen devamındaki şu beyitler de bu sıradanlığı iyice ortaya dökmektedir:

\footnotetext{
${ }^{4}$ Mecmua, 234a.

${ }^{5}$ Mecmua, 232b.
} 
'Aḳlımız yelkenini lücce-i girdāba atıp ${ }^{6}$

Gāh inip găh çıḳalım zevḳ̣le her dem yüzelim

Çünki Fevzī gözümüz ‘ 1rżına aṣlā yoḳ idi

Yārı zor ile țutup başını bir bir düzelim

Fevzî'de Nedîm tesiri çok barizdir. Gerek eda gerekse lügat olarak ona öykünen şairin şu beyitleri Nedîm'deki inceliği yakalama konusunda gayret içinde olduğunu gösteriyor:

Nāz-ile büyütmüş bilürüm dāyeleriñ hep ${ }^{7}$

Pek sevgilisiñ lākin efendim güç üzersin

Bir kerrecik olsun hele bezmiñde buluşdum

Mestāne baḳışlım ne güzel bāde süzersin

Fevzî’nin klasik tarzda yazmaya çalıştığı manzumelerinden ziyade dinî-tasavvufi şiirlerde daha başarıl1, daha güçlü bulduğumuzu söylemeliyiz. Bu tür şiirlerdeki başarısı samimiyetinden ileri geliyor olmalı. Edebiyatımızda "yâ Resûlallah" redifli yüzlerce naat yazılmıştır. Bu kervana dâhil olan Fevzî'nin;

Zuhūruñ bā'is-i kevn ü mekāndır yā Resūlallāh ${ }^{8}$

Cemāliñ țal' at-ı mihr-i cihāndır yā Resūlallāh

matla'lı gazeli, sadece bu başlangıç beytiyle değil bütünüyle güzel bir naattır.

Fevzî’nin bir Bektaşi olup olmadığını kesin olarak bilemiyoruz. Ancak mecmuasına aldığı 17 manzumenin üçünün Kerbela mersiyesi, üçünün ehl-i beyt övgüsünde yazılmış olmasına ilave olarak;

\section{Serdār-1 tarịkat esedullāh 'Alì' dir ${ }^{9}$ \\ Esrār-1 hakạiḳat Ḥāc1 Bektaş-1 Velì' dir}

beytiyle başlayan şiiri, onun Bektaşi değilse bile Bektaşi muhibbi veya Bektaşi-meşrep bir şair olduğuna şüphe bırakmaz. O, Hz. Peygamber için kaleme aldığ 1 naati kadar;

Ag̀la ey dīdelerim māh-1 mükerrem geldi ${ }^{10}$

Ya'n $\bar{i}$ dil-sūz-1 sitem rūz-1 Muharrem geldi

\footnotetext{
${ }^{6}$ Mecmua, 232b.

${ }^{7}$ Mecmua, 277b.

${ }^{8}$ Mecmua, 201a.

${ }^{9}$ Mecmua, 211a.

${ }^{10}$ Mecmua, 210b.
} 
matla'lı gazelinde olduğu gibi Muharremiye tarzında da çok samimidir ve samimiyeti nispetinde başarılıdır.

Mecmuadaki şiirleri arasında onun șiir anlayıșına dair de bazı işaretlere rastlamak mümkündür. O, şiir yazma meşgalesinin ancak "bilgi" ile mücehhez hâle geleceği düşüncesindedir: Bu noktada Fuzûlî ile örtüşmektedir. "Bil ki şiir söyleyebilmek de kendi başına ayrı bir ilimdir. Ve kemal nevilerinden çok i'tibarda olan bir şubedir. Buna inkâr edenler, onun zevkine erişemeyenler veya şiir söylemesini beceremeyenlerdir." (Tarlan, 2018: 7) diyen Fuzûlî gibi düşünen Fevzî’ye göre "Cahil kişinin sözleri dizilmiş parlak inciler gibi sıralansa, vezne uydurulup nazmedilmiş hâliyle dahi 'sulu boncuk' sayıllı":

\section{Cāhiliñ sözleri gerçi dür-i meknūn olsa ${ }^{11}$}

Șulu boncuḳ șayılır naẓmla mevzūn olsa

Fevzî'nin muamma ile de iştigal ettiğini yine mecmuadaki bir şiirinden anlıyoruz. Klasik şiirimizin çözümü zor muammaları gibi olmasa da aşağıdaki basit muammayı kaleme almış olmas ${ }^{12}$ böyle bir gayretin de içinde olduğunu gösteriyor:

İnceden ince hisāb itdüm bu sāl ${ }^{13}$

Bayramuñ başında altmışdır yaşı̃

Bu ḳadar sa ${ }^{c}$ yla buldum hyayr-1 fâl

Ġayrı rāḥat bulsun ey cānım başıñ

Fevzî’nin bir şiiri de Mir'âtî mahlaslı bir şaire naziredir. Diğer şairler için yaptığı gibi kendi şiirlerini de ya şiirin başında ya da derkenarda olmak üzere kırmızı mürekkeple bir başlık hâlinde şiirlerin sahibini yazmıştır. Kendi şiirlerindeki başlıklarda kendisini çoğunlukla tevazu ifadeleriyle takdim etmiştir.

\section{FEVZÎ'NİN ȘİRLERİ ${ }^{14}$}

\section{Mersiye-i İmām-1 Kerbelā Raḍiya'l-lāhu 'Anhu ${ }^{15}$}

Vezin: ..--/..--/..--/..-

Mihnnet-i pür-elem[i] sinede her dem țutarız

Giyeriz karaları nāle-i mātem țutarız

Kerbelā vak ${ }^{`}$ asını yāreye merhem țutarız

O Yezīd-i dīn düşmānımızı kem țutarız ${ }^{16}$

\footnotetext{
${ }^{11}$ Mecmua, 243b.

${ }^{12}$ Fevzî burada ebced hesabı ile; bayram, yani Arapça ‘îd/'1yd (عبد) kelimesinin başına yine ebced hesabına göre 60 sayısına tekabül eden sin (س) harfi getirilerek, muammanın cevabının Sa'îd (سعيد) olacağını belirtmiştir. Klasik gelenekte aslında muammanın başında cevabı da, yani o muammada gizlenen isim de yazar. Muhtemelen basit olduğu için Fevzî cevabı yazmaya gerek görmemiştir.

${ }^{13}$ Mecmua, 20b.

14 Buradaki şiirler, mecmuadaki sıraya göre değil "dîvân tertibine" göre sıralanarak verilmiştir. Her şiirin başında mecmuada yer aldığı sayfa numarası gösterilmiştir. Ayet, hadis ve Arapça ibareler italik karakterde dizilmiştir. Metinde aruzla ilgili (zihaflı seslerin italik yazılması vb.) tasarruflarda M. Fatih Köksal'ın makalesindeki (Köksal 2009) tekliflerine uyulmuştur. Eklerin yazımında metindeki imla gözetilmiştir.

${ }_{15}$ Mecmua, 107a. Derkenara “Efḳaru'l-fuḳarā ve türāb-1 aḳdāmü’ş-şu'arā el-'arīf bi-İ̀sḥāḳ-zāde Fevzī-i ednā fì 29 Muharremi'l-ḥarām 1297” (12 Ocak 1880) notu düşülmüştür.

${ }^{16}$ Vezin kusurlu.
} 
La' netu'l-lāhu 'aleyh lafạını elzem țutarız

İtdiler şāh Ḥüseyn'e bu ḳadar ẓulm ü ežā

Kesdiler gerdenini düşdi zemīne hayfã

Ditredi bunca zamān arż u semā 'arş-1 'alā

O Yezīd-i dīn düşmānımızı kem țutarız

La'netu'l-lāhu 'aleyh lafẓını elzem țutarız

Bu hakāāātı hemān eylediler ehl-i fesād

Bā‘ iš-i fitne idi çünki o dem İbn-i Ziyād

Kadr-i vālāsını hiç bilmediler ḳavm-i 'inād

O Yezīd-i dīn düşmānımızı kem țutarız

La' netu'l-lāhu 'aleyh lafẓını elzem țutarız

Sürelim merḳadine Fevzīo şāhıñ yüzimüz

Ag̀layu ag̉layu al ḳana boyansun gözimüz

$\bar{A} l$ ü evlād-1 Resūl olsa 'aceb mi sözimüz

O Yezīd-i dīn düşmānımızı kem țutarız

La' netu'l-lāhu 'aleyh lafẓını elzem țutarız

Muharrir-i Hāze'l-Mecmū`a es-Seyyid Hูāfiz Ḥasan Fevzīi ${ }^{17}$

Vezin: --./.--./.--./.--

Gel [kim] güzelim meclise ag̉yār aralansun

Sỉnem yeñiden ḳaşıñ ucindan yaralansun

Kanlu cigerim bağn derūnum paralansun

Tek ben göreyim zülfüñi bahtım ḳaralansun

Țut aġzıma la' 1-i lebüñi āb-1 zülăldir

Dil-teşnelere āb-1 zülāl ' ayn-1 vișẩdir

Mir'āt-i cemāliñ ne cemāldir ne kemāldir

Tek ben göreyim zülfüñi bahtım ḳaralansun

Cānā huaț-1 ruhsārıñ̃ gül yüzden ayırma

Țursun aman ol gamzeleriñ gözden ayırma

Yansun hele Fevzī cigerin közden ayırma

Tek ben göreyim zülfüñi bahtım ḳaralansun

Der Na't-1 Ehl-i Beyt-i Resūil ${ }^{18}$

Vezin: --./.--./.--./.--

Serdār-1 tarīḳat esedullāh 'Alī'dir

Esrār-1 ḥaḳiḳat Ḥâà Bektaş-1 Velì’ dir

Evlād-1 resūlü'ș-șaḳaleyn ḳurretü'l-'ayneyn ${ }^{19}$

Gencīne-i hikmet dürer-i lem-yezelïdir

\footnotetext{
${ }^{17}$ Mecmua, 277a.

${ }^{18}$ Mecmua, 211a. Derkenara “İsḥāḳ-zāde Ḥāfiz Ḥasan Fevzī’niñdir” notu düşülmüş̧ür.

19 “Göz bebeği, göz sevinci, göz nuru” anlamlarına gelen Kurretü'l- 'aynen ibaresi Kur'ân'da üç yerde geçer: Furkân suresi 74,Kasas suresi 9 ve Secde suresi 17. ayetler (Yılmaz, 1992: 96). Burada sondaki -eyn ekiyle Hz. Muhammed'in torunları Hasan ve Hüseyin kastedilmiştir.
} 
Her hükm-i ḳader 'ilm-i ilāhīde muḳarrer

Bu vaḳ a-yı dil-sūz-1 Ḥüseynī ezelīdir

Ervāḥına la' net çekeriz ḳavm-i Yezīd'iñ

Anlar ki o dem ehl-i fesādıñ temelidir

S̄ābit-kademiz 'ahdimize Fevzī kaviyyiz

Bu va'd-i kerīmāne delỉ kālu belìdir ${ }^{20}$

Ġazel-i Diger li-Cenābi Mir 'ātī Kuddise Sırruhü ${ }^{21}$ *

Vezin: ..--/..--/..--/..-

Gene sālūs oturup ṣavm u salātın söyler

Cenneti halḳa șatup sīm ü berātın söyler

...

La fet $^{2}{ }^{2}$ bahrine taldı yine fülk-i Mir 'āt

Femi isneyn 'aşere ${ }^{23}$ remz-i cezātın söyler

Vezin: ..---..---..--/..- ${ }^{24}$

Çıkssa kürsīye șūfi medhle zāâtın söyler

Halḳı kandırmaḳ içün șidk u sebātın söyler

'Āş1ḳ-1 ehl-i yakịin bāb-1 tevekkül gözedir

Bir işāretle hemān ḥayy u memātın söyler

Ḥażret-i şāh Ḥasan ' aşḳına zehr-i sitemi

Nūş iden haş̧re degin āb-1 hayātın söyler

Hayder'iñ sırrını bilmek ise maḳsad zīrā

Țab ${ }^{c}-1$ nā-süftelerim cümle cihātın söyler

Çok zamāndır bilirim varța-i hicrānda idi

Hele `ālemde bugün Fevzīinecātın söyler

Muharrir-i Hāze'l-Mecmū' a Hasan Fevzī el-‘ Arīf bi-İshāk-zāde ${ }^{25}$

Vezin: --./.--./.--./.--

Āsār-1 vefā rū-yı dil-ārāda mı zāhir

Kālā-yı viṣăl kenz-i gevāhirde nevādir

Tașvīr-i ḩayālāt yine levḥ-i naẓarımda

Besbelli gezer kūy-1 ḥaremgāhda kāfir

\footnotetext{
${ }^{20}$ A'râf suresi 172. ayetten kısmî iktibastır. "Evet, Rabbimizsin dediler".

${ }^{21}$ Mecmua, 233b.

* Mir'âtî’ye ait bu gazelin matla ve makta beyitleri alınmıştır. Fevzî’nin bundan sonraki şiiri gazele naziredir.

${ }^{22}$ Tamamı "Lâ-fetâ illâ Alî lâ-seyfe illâ Zü’lfikâr" olup “Ali’den başka genç (yiğit, er), Zü’lfikâr'dan başka (keskin) k1lıç yoktur." (Ali gibi kahraman kimse, onun kılıcı gibi kılıç yoktur.)" (Yılmaz, 1992: 100) manasındaki sözden iktibastır.

23 "išneyn 'aşere": On iki. On iki imam kastedilmektedir.

${ }^{24}$ Mecmua, 234a. Bu şiirin başlığı yoktur.

${ }^{25}$ Mecmua, 258a.
} 
Ḩaț leşkeri meydān-1 cebīninde müheyyā

Müjgānları hūn-feşān itmede māhir

Ebrūları ta' 1 immle ok u yayını çekdi

Āhūlarını zīr-i kemend eyledi āhir

Kākülleri Fevzī ser-i sevdāda muḳayyed

Zülf-i siyehi fenn-i füsūn-sāzda sāhir

Diger Ġazel-i Fevzi ${ }^{-26}$

Vezin: ..--/..--/..--/..-

Ne çiçek oldıġını ġoncemiziñ pek bilürüz

Vașf-1 ta' rīfe ne hâacet anı gerçek bilürüz

' İlm-i șarfda oḳuduk dersini yāriñ ' acele

Vezn-i ' mef' ūlini bir parça hemān şek bilürüz

Çeşm-i cellād eger cānımıza ḳașd idiyor

O şekāvet-nazararı kıı ț a-i Hersek bilürüz

Nice mir'āt-i cemāl olsa nigāh eylemeyiz

$\mathrm{Bu}$ güzellikde o meh-pāremizi yeg bilürüz

Mār-1 gīsūlarını Fevzī perīṣān ideriz

Rūzigār meşrebimiz zülfini esmek bilürüz

Muharrir-i Hāz̄e'l-Mecmū' a Ḥasan Fevzī el-`Arīf bi-İsḥāḳ-zāde ${ }^{27}$

Vezin: -.--/-.---/-.--/-.--

Biz ki hasret çekmeden yok vuṣlata imkānımız

Kan döker țurmaz dem-ā-dem dīde-i giryānımız

Öyle bir gencīneye mālikleriz maḩfīdeyiz

Gerçi yoḳdur zerrece șūretde nām u şānımız

Bir cemāli şem'e hayrān olmuşuz pervāne-veş

Bārī yansın 'aşḳ odıyla büsbütün bu cānımız

Çünki bülbül-meşrebiz bir ġonceniñ dalında kim

Gü[n]-be-gün artar tükenmez āh-ile efḡānımız

Nice gündür derd-i ' $a$ aşk ile oñulmaz hasteyiz

Fevziyā ölmekden özge yoḳ-durur dermānımız

\footnotetext{
${ }^{26}$ Mecmua, 233a.
}

${ }^{27}$ Mecmua, 166b. 
Destūr Nuțke-1 Fevzī Der Hakḳk-1 Pīr Sa‘ de'd-dīn Cabbārī Ḳuddise Sırruhu'1-' Azīiz ${ }^{28}$

Vezin: -.---/-.--/-.---/-.-

Șahịib-i surr-1 velāyet Pīr $\mathrm{Sa}^{c}$ de'd-dīn imiş

Burc-1 eşrāf-1 sa'ādet Pīr Sa' de'd-dīn imiş

Melce'-i ḥācet revā kān-1 'aṭā luṭf-1 vefā

Kuṭb-1 akțāb-1 nihāyet Pīr Sa' de'd-dīn imiş

Āşiyān it ey dilā dil şehrini ežkārla

Ṭûț̣i-i kūy-1 belāgat Pīr Sac de'd-dīn imiş

Tā ḳıyāmet āsitān-1 dergeh-i pākin gözet

Çünki iksīr-i hidāyet Pïr Sa' de'd-dīn imiş

Ġonce-i bāg̀g-1 ḥakịịat ' andelīb-i ḩoş-nevā

Fevziyā bezm-i lețāfet Pīr Sac de'd-dīn imiş

Ve lehū Fevzîi

Vezin: --./.--./.--./.--

Ey dāg̀-1 derūnum yüri bir āhla ses çek

Mādām o güliñ bülbülüsüñ āh-1 ḳafes çek

Ālām iledir hạṣṣlı tahṣịil-i murādāt

Makṣūd bulunmaz hele bir parça heves çek

Bu nefs-i hevā ile amān başa çıḳılmaz

Gir bezm-i harābāta hemān țurma nefes çek

Baḳ baḳ ne güzel renge girer şāhid-i dilber Al yazma ile devlet-i iḳbāline fes çek

Fevzī n'ideyim '1yd-1 vișāliñ güni geçmiş Ġayrı cigeriñ hançer-i hicrānla kes çek

Ġazel-i Fevzī Der Ḥaḳk-1 Maḥbūbān ${ }^{30}$

Vezin: ..--/..--/..--/..-

Cilve-i būse-i maḥb übları her ān severim

Merhem-i vuṣlatını derdime dermān severim

Ne sebeb bülbülveş nale- giryān ideyim ${ }^{31}$

Çār ebrū meh-i ruhssār gül-i handān severim

İftihār itsem 'aceb mi ' acabā ‘ aşḳımla

Bir kerem șāhịibi sulțān-1 ' alì-şān severim

\footnotetext{
${ }^{28}$ Mecmua, $138 \mathrm{~b}$.

${ }^{29}$ Mecmua, 258b.

${ }^{30}$ Mecmua, 234a.

${ }^{31}$ Vezin kusurlu.
} 
Çekerim her gice àgūşa o nazik bedenin

Kimse āgāh olamaz sırrıma pinhān severim

Kāmet-i serv-i revān gerden-i billūr-mis̄āl

Öyle bir cān yaḳıcı āfet-i devrān severim

Avrupa perçemine Fevzī nigāhım olalı

Ol zamāndan berü gīsū-yı perişsān severim

Șāḥib-Muḥarrer FevZī Efendi'niñ Ġazeliyātınıñ $\mathrm{Ba}^{c}$ ż̀̄is1 $^{32}$

Vezin: ..--/..--/..--/..-

Acımaz hāal-i perişāanıma zīrā güzelim

Ne ise terk idelim dest-i ümidi üzelim

Çekelim ḥasretini añmayalım vușlatını

Gam-1 hicrān yerine bāde-i ' aşḳ̂ süzelim

Söyle ey bād-1 șabā bir gice teşrīf itsün

Tā țopuḳdan dize dek şalvar-1 vașlın çözelim

'Aḳlımız yelkenini lücce-i girdāba atıp

Gāh inip gāh çıkalım zevevkle her dem yüzelim

Çünki Fevzī gözümüz ' rrżına aṣlā yoḳ idi

Yārı zor ile țutup başını bir bir düzelim

Ve lehū Fevzîi

Vezin: --./.--./.--./.--

Ey ġamzesi cādū göz ucunda ne gezersin

Huışm-ile baḳarsın cigerim bag̉rım ezersin

Nāz-ile büyütmüş bilürüm dāyeleriñ hep

Pek sevgilisiñ lākin efendim güç üzersin

Bir kerrecik olsun hele bezmiñde buluşdum

Mestāne bakıışlım ne güzel bāde süzersin

Țurmaz ne idersin daha bu cevr ü cefãyı

Aḥvāl-i perişsānımı gördükçe sezersin

Āyine-i ruhsāriña Fevzī nice baḳsun

Her günde bir endāmıñı bir resme düzersin

Li-Muharririhỉ İsḥāḳ-zāde Fevzíi ${ }^{34}$

Vezin: .---/.---/.---/.---

Zuhūruñ bā' iș-i kevn ü mekāndır yā Resūlallāh

${ }^{32}$ Mecmua, 232b.

${ }^{33}$ Mecmua, 277b.

${ }^{34}$ Mecmua, 201a. 
Cemāliñ țal'at-1 mihr-i cihāndır yā Resūlallāh

Ḥarīm-i ravża-i pākiñ nazargāh-1 İlāhīdir

Nigāh-1 şefḳatiñ dārü'l-emāndır yā Resūlallāh

Ḥaḳiḳatde vücūd-1 gevher-i gencīne-i zāâtıñ

Rumùz-1 küntü kenz ${ }^{35}$ içre nihāndır yā Resūlallāh

Tudagiıñ havż̇-1 kevserdir boyuñ bir serv-i țūbādur

Mübārek hāā-i pāyıñ gülsitāndır yā Resūlallāh

Viṣāliñ hasretiyle Fevzīi bỉ-çāreyi gör kim

Gice gündüz işi āh u fig̀āndır yā Resūlallāh

Der Ḥaḳk-1 Muhibb-i Āl ü Evlād Radiy[allāhu] 'Anhümā Rabbü'l-‘ ibād ${ }^{36}$

Vezin: --./.--./.--./.--

Sancak-1 res $\bar{u}$ tì $\dot{\mathrm{g}}-1$ teberd $\bar{x}$ belimizde

Bir dürr-i yetīm kenz-i güherdir elimizde

Ey șūfī bizim șūretimiz bād-1 şitādır

Esrār-1 hüveydā eser olmaz yelimizde

Āsār-1 maḥabbet cereyān itdigi demler

Pür-hūunla ālūde sirişk-i selimizde

Mādām ki üftādeleriz melce'imizdir

Evlād-1 'Alì yād olur elbet dilimizde

Ġam mı çekeriz cürmümüzüñ ` afvına Fevzī

Elțāf u kerem hạżret-i şāh-1 ' Alīmizde

Ġazel-i Diger Li-Cenābi Fevzi ${ }^{-37}$

Vezin: ..--/..--/..--/..-

Cāhiliñ sözleri gerçi dür-i meknūn olsa

Șulu boncuḳ șayılır naẓmla mevzūn olsa

' İlel-i ' aşḳa tedābīr-i hekīm nāfiledir

Bulamaz çāresini dahı Felāțūn olsa

Yine erkek dikecekdir mūmını haşre degin

Kadınıñ her ne kadar şemdānı altun olsa

Tog̀sa hurşīid-i cemālim bu karanlık gitse

Hele görsem yüzini bār $i$ biraz gün olsa

Kara sevdālara āḩir düşürür Fevzīi anı

35 Tamamı "Ben, gizli bir hazine idim, bilinmeyi diledim..." (Yılmaz, 1992: 91) mealindeki hadis-i kudsîden kısmî iktibas.

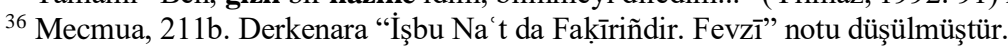

${ }^{37}$ Mecmua, 243b. 
Kim ki bir zülf-i sitem-kāreye meftūn olsa Mersiye vü Mātemiye ${ }^{38}$

Vezin: ..--/..--/..--/..-

Ag̀la ey dīdelerim māh-1 mükerrem geldi

$Y^{c} a^{c} n \bar{i}$ dil-sūz-1 sitem rūz-1 Muharrem geldi

Kurretü'l- 'ayn-1 resūlü'ṣ-șaḳaleyn şāh Ḥüseyn

Biñ belā ile şehīd oldig̀i ol dem geldi

Kerbelā vaḳ asıdır mūcib-i hicrān [u] elem

Ṣanma ki derdimize ș̣ḥhat u merhem geldi

O Yezīd-i dīn düşmanımıza șubh u mesa ${ }^{39}$

La' netu'l-lāhi ‘aleyh herkese elzem geldi

Nice āh eylemesin Fevzz̄ ciger-hūn olanıñ

Çeşme-i çeşmine çün nāle-i mātem geldi

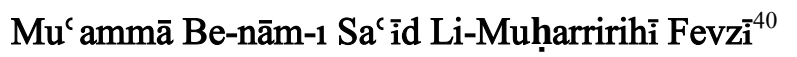

Vezin: -.---/.---/-.-

İnceden ince hisāb itdim bu sāl

Bayramıñ başında altmışdır yaşıñ

Bu ḳadar sa ${ }^{\top}$ yla buldum hayr-1 fâl

Ġayrı rāḥat bulsun ey cānım başıñ

\section{Sonuç}

Önceleri sırtında sazı ile Anadolu'ya yer yer uzun soluklu seyahatler yapan İshâk-zâde Fevzî, ilerleyen dönemde klasik şiir tarzında manzumeler kaleme almaya başlamıştır. Onun mecmuası, başta Kastamonu olmak üzere Amasya, Çankırı gibi illerdeki yerel şairlerin şiirleriyle Alevi-Bektaşi zümresine mensup şairleri ihtiva etmesi bakımından oldukça önemlidir. $O$, derlemiş olduğu mecmuasında kendi şiirlerine de yer vermiştir. Mecmuadaki şiirlerinde sıklıkla Hz. Ali, Hz. Hüseyin ve Hz. Hasan'ı anmakta, özellikle de Kerbela vakasına göndermeler yapmaktadır. Yer yer âşıkane ve rindane gazeller de söyleyen şair, mecmuasında bir de muammaya yer vermiştir.

Son dönem klasik Türk şiirinde, yaşanan hayatın klasik şiire önceki devirlerden daha kuvvetli bir şekilde tesir ettiği, şiire birçok yeni, yerel hatta Avrupaî unsurların rahatlıkla görülebildiği bilinen bir husustur. Bu durumun bariz tezahürlerini Fevzî’nin şiirlerinde de görmek mümkündür. Onun hususiyle klasik tarzda yazdığı şiirlerinde özellikle Nedîm tesirleri pek barizdir. Ne var ki muakkibi olduğu şairdeki zarafeti, letafeti ve kıvraklığı yakalayamamıştır.

Fevzî'nin şiirlerinde, bir yanıyla dervişane ama aynı zamanda bir ucundan da hayata sağlam iple bağlı bir tavır sezilmektedir. O bu tavrıyla sadece şiir anlayışını ortaya koymuyor, kuşkusuz hayat anlayışını da resmediyordu. Bir yandan mistik-irfanî tarza, bir yanıyla klasik şiire, bir yanıyla da halk şiirine bakan Fevzî’nin büyük Türk edebiyatının her kaynağından beslenme arzusunda olduğu açıkça sezilmektedir. Bu yönüyle onun bir bakıma Anadolu'da gelişen XIX. yüzyıl şiir geleneğinin ortalama bir temsilcisi olduğunu söylemek de mümkündür.

\footnotetext{
${ }^{38}$ Mecmua, 210b. Derkenara “Ṣāḥib-taḥrīrāt İsḥāḳ-zāde Ḥāfiz Ḥasan Fevzī bendeleriniñdir” notu düşülmüştür.

${ }^{39}$ Vezin kusurlu.

${ }^{40}$ Mecmua, 20b
} 


\section{Kaynakça}

Aydın, Abdullah (2019). Kastamonulu Divan Şairleri. Sonçağ Akademi.

Çelengil, M. Nasıh (1944). "Kastamonu Şairleri: Âşık Fevzî”. Ecevit, S. 7, 6-7.

Halıcı, Gülşah Yüksel (2013). "Fevzî, Hasan”. Türk Edebiyatı İsimler Sözlüğü. Erişim Tarihi: 21.03.2020). http://teis.yesevi.edu.tr/madde-detay/fevzi-hasan

Kaçalin, Mustafa (2003). "Kastamonulu Şairler”. II. Kastamonu Kültür Sempozyumu Bildirileri 1820 Eylül 2003. Ankara: Kastamonu Valiliği Yayını, 271-288.

Kılıç, Filiz (2003). "Şairler Tezkirelerine Göre Kastamonulu Divan Şairleri”. II. Kastamonu Kültür Seтроzуити Bildirileri 18-20 Eylül 2003. Ankara: Kastamonu Valiliği Yayını, 243-256.

Köksal, M. Fatih (2009). "Metin Neşrinde Vezinle İlgili Problemler, Bazı Tespit ve Teklifler”, Divan Edebiyatı Araştırmaları Dergisi, S. 3, 63-86.

Köksal, M. Fatih (2010). "Bir Şiir Mecmuasından Hareketle Kerbelâ Literatürüne Ekler”. Çeşitli Yönleriyle Kerbelâ. Uluslararası Kerbelâ Sempozyumu 20-22 Mayıs 2010, Sivas. Sivas: Cumhuriyet Üniversitesi Yayını: 351-378.

Köksal, M. Fatih (2011). "Biyografik Kaynak Olarak Şiir Mecmuaları ve Kastamonulu İshâkzâde Fevzî Mecmuası", Prof. Dr. Mustafa İsen Adına Uluslararası Klâsik Türk Edebiyatında Biyografi Sempozyumu Bildiriler, Nevşehir Üniversitesi, 6-8 Mayıs 2010, Nevşehir, Ankara: AKM Yayın1, 449-467.

Köksal, M. Fatih (2013). "Bâkî'nin Bilinmeyen Veda Gazeli ve Dîvânında Bulunmayan Bazı Şiirleri”. Divan Edebiyatı Araştırmaları Dergisi. S. 10, 319-330.

Köksal, M. Fatih, Mücahit Kaçar, Mevlüt İlhan (2018). Prof. Dr. Mehmet Fatih Köksal Kütüphanesi Türkçe El Yazmaları Kataloğu. Kesit Yayınları.

Mengi, Mine (2017). Eski Türk Edebiyatı Tarihi. Akçağ Yayınları.

Ozanoğlu, İhsan (1939). “Kastamonulu Âşık Fevzî Hayatı ve Eserleri”, Kopuz, S. 6, 226-227.

Şenel, Süleyman (1995). "Kastamonulu Halk Şairleri Üzerine”. Türkiye İş Bankası Kültür ve Sanat Dergisi, 27-48.

Tan, Nail (2015). “Kastamonulu Âşık Kemâlî Bibliyografyası”. Kültür Evreni, S. 23, 105-112.

Tan, Nail (1987). "Kastamonu Halk Şairleri”. II. Uluslararası Türk Halk Edebiyatı Semineri Bildirileri, Eskişehir, 348.

Tan, Nail, Özdemir Tan (2004), “Âşık Fevzî”, Gurur Kaynağımız Kastamonulular. C. 3, s. 68-70.

Tarlan, Ali Nihat (2018). Fuzûlî Divanı Şerhi. Ankara: Akçağ Yayınları.

Yaman, Talat Mümtaz (1936). "Fevzî Hayatı ve Eserleri”. Ilgas Dergisi, S.2, 12-13.

Yazar, İlyas (2005). "Kastamonulu Divan Şairleri”. II. Kastamonu Kültür Sempozyumu Bildirileri 18-20 Eylül 2003. Ankara: Kastamonu Valiliği Yayını, 255-264.

Yılmaz, Mehmet (2013). Kültürümüzde Ayet ve Hadisler. Kesit Yayınları.

Yücel, Neslihan (1993). Kastamonu'da Âşıklık Geleneği ve Kastamonu'da Yetişsen Âşılklar. Gazi Üniversitesi Sosyal Bilimler Enstitüsü. 